\title{
Correction to: Co-expression network analysis identified key genes in association with mesenchymal stem cell osteogenic differentiation
}

\author{
Wang Yang ${ }^{1,2} \cdot$ Yuhan Xia $^{1} \cdot$ Xiaoli Qian ${ }^{1} \cdot$ Meijing Wang ${ }^{1} \cdot$ Xiaoling Zhang ${ }^{3,4} \cdot$ Yulin $\mathrm{Li}^{1} \cdot \mathrm{Lisha}^{\mathrm{Li}}{ }^{1}$ \\ Published online: 21 October 2019 \\ (C) Springer-Verlag GmbH Germany, part of Springer Nature 2019
}

\section{Correction to: Cell Tissue Res (2019) https://doi.org/10.1007/s00441-019-03071-1}

The authors regret that in our published paper entitled "Coexpression network analysis identified key genes in association with mesenchymal stem cell osteogenic differentiation" Cell Tissue Res (2019). https://doi.org/10. 1007/s00441-019-03071-1; there is a typo in the text that appears in the "Material and method_Co-expression network construction". We mistakenly wrote GSE58919 as GSE658919.

The error in the Table 2 was that the Table 2 was not fully displayed.

The authors would like to apologize for any inconvenience made by this mistake.
Therefore, in our article we make the following corrigendum in the text:

1) Page 2, Material and method, ("Co-expression network construction"), last paragraph. Consequently, the text has the following changes (for the changes, see underlined text).

"In this study, the soft threshold in GSE658919 is 16 while the soft threshold in GSE18043 is 14". GSE658919 should be corrected to GSE58919.

2) Page 12, Table 2, ("Characteristics of potential key genes in MSC osteogenic differentiation"). Replacement for Table 2 showing the correct information is displayed below.

The online version of the original article can be found at https://doi.org/ 10.1007/s00441-019-03071-1

Xiaoling Zhang

zhangx1714@sina.com

Yulin Li

ylli@jlu.edu.cn

Lisha Li

43973966@qq.com

1 The Key Laboratory of Pathobiology, Ministry of Education, Norman Bethune College of Medicine, Jilin University, Changchun 130021, China

2 College of Clinical Medicine, Jilin University, Changchun, China

3 The First Hospital, Jilin University, Changchun 130061, China

4 Institute of Immunology, Jilin University, Changchun 130061, China 
Table 2 Characteristics of potential key genes in MSC osteogenic differentiation

\begin{tabular}{|c|c|c|c|c|}
\hline Symbol & Description & $\begin{array}{l}\text { GO-Biological Process } \\
\text { and KEGG pathway }\end{array}$ & Function & Reference \\
\hline ССТ2 & $\begin{array}{l}\text { T-complex protein } \\
1 \text { subunit beta }\end{array}$ & NA & $\begin{array}{l}\text { Cell cycle and osteoblast } \\
\text { differentiation }\end{array}$ & $\begin{array}{l}\text { (Minegishi, et al., 2018, } \\
\text { Alves, et al., 2010) }\end{array}$ \\
\hline NOP58 & Nucleolar protein 58 & $\begin{array}{l}\text { Ribosome biogenesis } \\
\text { in eukaryotes }\end{array}$ & $\begin{array}{l}\text { Influence 2'-O-methylation } \\
\text { of rRNAs to regulated the } \\
\text { proliferation }\end{array}$ & (Qin, et al., 2017) \\
\hline FBL & Fibrillarin & & $\begin{array}{l}\text { Influence 2'-O-methylation } \\
\text { of rRNAs to regulated the } \\
\text { proliferation and regulate } \\
\text { differentiation }\end{array}$ & $\begin{array}{l}\text { (Bouffard, et al., 2018, } \\
\text { Watanabe-Susaki, et al., } \\
\text { 2014, Shubina, et al., 2016) }\end{array}$ \\
\hline PSMC6 & $\begin{array}{l}\text { Proteasome } 26 \mathrm{~S} \text { subunit, } \\
\text { ATPase } 6\end{array}$ & $\begin{array}{l}\text { Wnt signaling pathway, } \\
\text { amino acid metabolic }\end{array}$ & $\begin{array}{l}\text { Participate in stem cell } \\
\text { differentiation and }\end{array}$ & $\begin{array}{l}\text { (Vilchez, et al., 2012, } \\
\text { Koyuncu, et al., 2018, }\end{array}$ \\
\hline PSMB7 & Proteasome subunit beta 7 & process and proteasome & self-renewal & Saez, et al., 2018) \\
\hline EXOSC8 & exosome component 8 & NA & $\begin{array}{r}\text { Correct neuronal } \\
\text { differentiation }\end{array}$ & $\begin{array}{l}\text { (Giunta, et al., 2016, } \\
\text { Lloret-Llinares, et al., 2018, } \\
\text { Makino, et al., 2013) }\end{array}$ \\
\hline SNRPD1 & $\begin{array}{l}\text { small nuclear } \\
\text { ribonucleoprotein } \\
\text { D1 polypeptide }\end{array}$ & NA & $\begin{array}{l}\text { Interacts with cajal body } \\
\text { to regulate transcription }\end{array}$ & $\begin{array}{l}\text { (Smolinski and } \\
\text { Kolowerzo, 2012) }\end{array}$ \\
\hline
\end{tabular}

Publisher's note Springer Nature remains neutral with regard to jurisdictional claims in published maps and institutional affiliations. 